\title{
Corporate governance attributes, firm characteristics and the level of corporate disclosure: Evidence from the Indian listed firms
}

\author{
Sunil Nandi ${ }^{\mathbf{a}^{*}}$ and Santanu Kumar Ghosh ${ }^{\mathrm{b}}$
}

${ }^{a}$ Assistant Professor, Department of Commerce, Rajiv Gandhi University, Rono Hills, P. O. Doimukh-791112, Arunachal Pradesh, India ${ }^{b}$ Professor, Department of Commerce, The University of Burdwan, Post Office: - Rajbati, District: - Burdwan, Pin - 713104, West Bengal, India

\section{H R O N I C L E}

Article history:

Received July 25, 2012

Accepted October 10, 2012

Available online

October 182012

Keywords:

Firm characteristics

Corporate governance attributes

Corporate disclosure

India

\section{A B S T R A C T}

\begin{abstract}
This study investigates the association between firm characteristics, corporate governance attributes and the level of corporate disclosure of listed firms in India. The research paper has been based on a sample of 60 firms listed in the Bombay Stock Exchange (BSE) / National Stock Exchange (NSE) during the study period from 2000-01 to 2009-10. The study has used the Standard \& Poor (2008) model for measuring the level of corporate disclosure. To examine the association between explanatory variables and the level of corporate disclosure, multiple regression model has been used. The results suggest a positive relationship between board size, ratio of audit committee members to total board members, family control, CEO duality, firm size, profitability, liquidity and the extent of corporate disclosure. However, the degree of corporate disclosure is negatively related to board composition, leverage and age of the firm.
\end{abstract}

(c) 2013 Growing Science Ltd. All rights reserved.

\section{Introduction}

In recent years, several scandals and scams concerning the activities of the business enterprises have occurred around the globe. Due to these corporate failures, the importance of corporate disclosure has been increasing day by day. Annual report is the most important medium of the reported transparency and corporate disclosure practices. But published annual reports do not fulfill the need of the interested parties because managers are likely to consider their own interests when exercising managerial decision. Less information disclosure in the annual reports creates information asymmetry.

Higher level of corporate disclosure in the financial reports reduces the information asymmetry between companies and the investors, enhances the value of stock in the capital market and increases liquidity (Karim, 1996). In fact, lower level of corporate disclosure increases the difference between expected and actual disclosures. The levels of corporate disclosure vary from firm to firm, industry to industry and also from country to country. The decision to provide or not to provide certain essential

* Corresponding author. :Tel: +919402965330

E-mail addresses: sunilnandi2008@gmail.com (S.Nandi)

(C) 2012 Growing Science Ltd. All rights reserved. doi: $10.5267 /$ j.dsl.2012.10.004 
information is likely to be influenced by a variety of factors like board size, ratio of audit committee members to total board members, board composition, non-executive directors, independent directors, family control, CEO duality, firm size, profitability, leverage, liquidity, ownership structure, assets-in-place and age of the firm. Hence, the present study is designed to find out their relations with the level of corporate disclosure. Earlier research studies examine various firm characteristics and their relationship with the degree of voluntary corporate disclosure (Firth, 1979; Cooke, 1989; Owusu-Ansah, 1998; Ho \& Wong, 2001; Chau \& Gray, 2002; Aktaruddin, 2005; Narasimhan \& Vijayalakshmi, 2006; Hossain \& Hammami, 2009).

Negligible research works have been done in the Indian context, to examine the relationship between firm characteristics, corporate governance attributes and the degree of corporate disclosure. This study examines the association between firm characteristics, corporate governance attributes and the level of corporate disclosure.

The remainder of the research paper is organized as follows. Section two discusses the objective of the study. Section three presents a review of the literature and develops the study's hypotheses. The research method is outlined in Section four. Section five presents the results. Section six discusses the conclusions. Finally, Section seven presents the limitations and directions for future research.

\section{Objective of the Study}

The primary objective of this study is to examine the association between firm characteristics, corporate governance attributes and the extent of corporate disclosure of the 60 listed firms operating in India.

\section{Review of Literature and Hypothesis Development}

\subsection{Review of Literature}

Demand for corporate disclosure and financial reporting increases day by day due to agency conflicts and information asymmetry between managers and outside investors (Healy \& Palepu, 2001). In the emerging markets, information asymmetry is high due to lower level of transparency (Jensen \& Meckling, 1976). By disclosing more information the agency cost of that firm is also expected to be reduced. Various factors have been acknowledged by the earlier researchers which play important roles in reducing the informational gap between the management and the stakeholders. Firm characteristics as well as corporate governance attributes in this respect are considered to be important (Ahmed \& Courtis, 1999; Ho \& Wong, 2001; Chau \& Gray, 2002; Haniffa \& Cooke, 2002; Eng \& Mak (2003); Aktaruddin, 2005; Narasimhan \& Vijayalakshmi, 2006; Barako et al., 2006; Aljifri, 2008; Hossain, 2008; Hossain \& Hammami, 2009; Akhtartuddin et al., 2009; Rouf, 2010). Following the views of the abovementioned researchers it may be expected that the decision to disclose or not to disclose adequate information is likely to be influenced by a variety of factors like board size, family control, CEO duality, firm size, liquidity, leverage, profitability and age of the firm. Akhtaruddin et al. (2009) have studied the association between corporate governance and the level of voluntary disclosure. The results of the study show that the degree of voluntary disclosure is positively associated with the board size and the proportion of independent non-executive directors on the board, while the ratio of the audit committee members on the board is not associated with the level of voluntary disclosure.

Board size refers to the total number of members exists in the body of Board of Directors. Bigger boards are superior for corporate performance because they have more experience people in the board 
that may help for quick and better decisions. Several previous research studies have found a significant association between these two variables (Akhtaruddin et al., 2009; Allegrini \& Greco, 2011).

Hossain (2008) has found that board composition of a firm may be an important determinant of corporate disclosure level. Several previous research studies have found a significant association between these two variables (Haniffa \& Cooke, 2002; Akhtartuddin, et al., 2009). Family control is an important corporate governance attribute because a large number of firms are owned and controlled by the families in the East Asia (Ho \& Wong, 2001). In case of family-controlled firms, family members usually have important positions both on the team of management and on the board of directors. It is expected that, family-controlled firms have inferior corporate governance and lower accountability because of ineffective monitoring by the board of directors. CEO duality and ratio of audit committee members to total board members, these two corporate governance attributes have also been used in some previous research studies (Barako et al., 2006; Ho \& Wong, 2001; Rouf, 2010).

Firm size has persistently been found to be significantly and positively associated with the corporate disclosure levels in several studies, suggesting that bigger firms follow better corporate disclosure practices (Singhvi \& Desai, 1971; Firth, 1979; Cooke, 1989; Ho \& Wong, 2001; Akhtaruddin, 2005; Narasimhan \& Vijayalakshmi, 2006).

Cooke (1989) has argued that a highly profitable firm is more likely to signal to the market its superior performance by disclosing more information in its annual report. A significant positive relationship has been found in some previous studies (Singhvi \& Desai, 1971; Wallace et al., 1994; Haniffa \& Cooke, 2002).

Jensen \& Meckling (1976) have argued that highly leveraged firm may disclose more information in annual reports for reducing the monitoring costs of said firm. A positive relationship has been found between leverage and the level of corporate disclosure (Hossain et al, 1994). Liquidity (Wallace et al, 1994; Wallace \& Naser, 1995) and age of the firm (Owusu-Ansah, 1998; Aktharuddin, 2005) also been used in some previous research studies as firm characters. In the Indian context, limited research works have been conducted by using the above firm characteristics and corporate governance attribute as explanatory variables. The present study, therefore, makes a modest attempt to fill in this research gap in the Indian context. In order to fulfill this research gap ten hypotheses have been formed and tested. Following section is devoted for this purpose.

\subsection{Hypothesis Development}

For development of the testable hypothesis it is necessary to identify the theoretical and / or a-priori relationship between the variables which have been employed in the present study.

\subsubsection{Corporate Governance Attributes}

\section{Board Size}

Board size is an important corporate governance attribute. Board size has a positive influence on the level of corporate voluntary disclosure (Akhtartuddin et al., 2009). Larger boards are better for corporate performance because they have a wide range of collective experience and expertise that may help for better decisions. A large number of directors on the board can reduce the probability of information asymmetry (Chen \& Jaggi, 2000). The board size has an effect on the ability of the board to monitor and evaluate management (Zahra et al., 2000). Further, the ability of directors to control 
and promote value creating activities is more likely to increase with the increase of directors on the board. Hence, it is hypothesized that:

\section{$H_{1}$ : The degree of corporate disclosure is higher for firms with a big board size.}

\section{Board Composition}

The purpose of considering board composition is to identify the proportion of non-executive directors on the board and to assess its impact on the quality of disclosures made through financial reports. The quality of corporate disclosure enhances when the proportion of the independent director on the board raises (Fama \& Jensen, 1983). Haniffa \& Cooke (2002) has provided empirical evidence of the association between the proportion of non-executive directors on the board and the degree of voluntary disclosure. Our research study examines the influence of non-executive directors as an important component of corporate governance mechanism on the corporate disclosure practices in India. It is generally held that higher proportion of non-executive directors reduces information asymmetry. Hence, it may be hypothesized that:

\section{$\mathrm{H}_{2}$ : A higher ratio of non-executive directors on a board is positively related to the degree of corporate disclosure.}

Ratio of Audit Committee

Effective audit committees are expected to improve the financial reporting quality by fulfilling its various responsibilities including, implementing appropriate accounting policies, reviewing the accounts including financial statements and reviewing the sufficiency of internal controls. Also audit committee plays an important role in appointing and in determining the remuneration of the external auditors. It is also empowered to review the auditors work. As a result, audit committee acts as a monitoring mechanism and audit committee can help to improve the overall quality of information flows between managers and the different interested parties. Audit committee, therefore, may play a key role in improving the financial reporting practices which, in turn, is expected to bring down the information asymmetry. While most of the earlier studies have sought to examine the influence of audit committee on the degree of corporate disclosure, present study proposes to use the size of the audit committee as the explanatory variable. A similar research work which has been reported by Akhtartuddin et al., (2009) in the Malaysian context, evidences insignificant positive association between size of the audit committee and the degree of corporate voluntary disclosure. Present study seeks to investigate this issue in the Indian context and accordingly it is hypothesized that:

\section{$\mathrm{H}_{3}$ : The level of corporate disclosure is positively associated with the proportion of audit committee members to total members on a board.}

Family Control

Firms with wider ownership are likely to disclose more information compared to family-controlled firms because the demand for information is high in case of widely held firms (Chau \& Gray, 2002). Family control is an important corporate governance attribute in India because a large number of firms owned and controlled by families (Moody's-ICRA Corporate Finance, 2007). In case of familycontrolled firms, family members usually occupy important positions both on the team of management and on the board of directors. It is, therefore, expected that family-controlled firms have inferior corporate governance and lower accountability because of ineffective monitoring by the board of directors. Family controlled firm's performance is lower than that of the firms which are controlled by the institutional investors (Piesse et al., 2007). It may, therefore, be hypothesized that:

$\mathrm{H}_{4}$ : Family control is negatively associated to the level of corporate disclosure. 


\section{CEO Duality}

CEO duality is an important corporate governance element to every concern in the world. CEO duality is said to be present in a concern, when the same person does not perform both the role of Chief Executive Officer (CEO) and Chairman of the board of directors. Unitary leadership structure (where the role of CEO and Chairman of the board is performed by the same person) does not support the principle of separation of decision management and decision control (Fama \& Jensen, 1983). According to agency theory, the important function of a board can be damaged by the unitary leadership structure. CEO may be engaged in some opportunistic behavior with a unitary leadership structured firm because of his / her dominance over the board. Duality gives a great understanding and knowledge of the firms operating environment that should impact positively on firm performance. The following specific hypothesis has been tested regarding CEO duality: $\mathrm{H}_{5}$ : The extent of corporate disclosure is higher for firms with a dual leadership structure.

\subsubsection{Firm Characteristics}

\section{Firm Size}

Large firms have higher agency costs than smaller firms (Jensen \& Meckling, 1976; Leftwich et al., 1981). Moreover, large firms are more visible than smaller firms and, as a result, more exposed to public interest (Watts \& Zimmerman, 1986). Due to fear of competition, small firms will disclose less information than large firms (Singhvi \& Desai, 1971). Most of the previous research studies have found significantly positive relationship between the firm size and the level of corporate disclosure (Singhvi \& Desai, 1971; Cooke, 1989; Hossain et al., 1994; Haniffa \& Cooke, 2002; Narasimhan \& Vijayalakshmi, 2006; Das et al., 2008).

A plausible explanation of this positive association may be that the larger firms disclose more information than the small firms for attracting prospective investors in the capital market. More information provided in the financial reports enhances the confidence of the investors (Nagina, 2005) and hence, it is hypothesized that:

$H_{6}$ : The degree of corporate disclosures is positively related with the size of the firm.

\section{Profitability}

According to signaling theory, profitable firms will disclose more information in the annual report to differentiate themselves from poorer performers. Managers are motivated to disclosure more financial information to support the continuance of their positions and remuneration and to signal institutional confidence (Rouf, 2010). Most researchers have found positive relationship between profitability and the extent of disclosure (see for example, Singhvi \& Desai, 1971; Wallace et al., 1994; Wallace \& Naser, 1995; Raffournier, 1995; Haniffa \& Cooke, 2002; Hossain, 2008). In this research study, profitability has been measured by net profit ratios. Based on the arguments mentioned above present study proposes the following hypothesis:

\section{$H_{7}$ : There is a positive association between profitability and the level of corporate disclosure. Leverage}

Incidence of high monitoring of the firm by the loan providers takes place in case of a firm which uses high level of debt in its capital structure. The cost, associated with the use of debt that may be referred to as 'monitoring cost' may come down if the degree of corporate disclosure increases (Jensen \& Meckling, 1976). Thus, for reducing the monitoring costs, firms are expected to disclose 
more information i.e. the association between the level of corporate disclosure and leverage is likely to be positive [Jensen \& Meckling, 1976; Aksu \& Kosedag, 2005). Financial leverage, may, therefore, be expected to influence the extent / degree of voluntary disclosure because a heavily leveraged firm has a greater urge to satisfy the demand for information by its long-term creditors (Chow \& Wong-Boren, 1987). Based on this proposition, it is hypothesized that:

$H_{8}$ : Leverage is positively associated with the level of corporate disclosure.

\section{Liquidity}

Liquidity being an important firm characteristic has not widely used as an explanatory variable in the previous studies. Firms holding large amount of current assets (high degree of liquidity) has certainly employed the costlier long-term funds in current assets instead of using them to earn at a higher rate through investments in fixed assets. This may raise doubt among the providers of long-term funds about the firms' efficiency in managing its finance. Under such a situation, a firm may not be a good choice among the investing community. In order to relieve the anxiety of the stakeholders including that of the investing community or in other words, in order to earn their patronage the firm may feel extra motivation to provide adequate information relating to its operational efficiency.

Based on this proposition it is expected that liquidity is positively correlated with the corporate disclosure level. Wallace et al. (1994), Wallace \& Naser (1995) have used this firm character for conducting their research studies. Several financial ratios can be used to evaluate the liquidity position of a firm. Those ratios are the current ratio, the quick ratio or acid test ratio and net working capital. In a previous study by Ghosh \& Nandi (2009) a positive association has been observed between the degree of corporate disclosure and liquidity. This earlier finding prompts us to hypothesize that:

\section{$H_{9}$ : Liquidity is positively related with the extent of corporate disclosure.}

\section{Age of the Firm}

The level of a firm's disclosure may be influenced by its age, i.e. stage of development and growth (Owusu-Ansah, 1998; Aktharuddin, 2005). Owusu-Ansah (1998) has pointed out three factors that may contribute to this phenomenon. Firstly, younger companies may suffer from competition. Secondly, the cost as well as the complexity and hazards of gathering and processing the required information may be a contributory factor, and finally, younger companies may lack an attractive track record to report. Newer firms may have some problems like lack of capital, brand name and reputation compared to the older firms. It is, therefore, expected that, the long-established firms may disclose more information or be more compliant than the newly-established firms. The age variable has been used in some earlier research studies (Aktharuddin, 2005; Hossain, 2008). But no significant association has been reported by both the studies. In the present study, however, a positive association is expected in the Indian context and accordingly, following hypothesis is proposed and tested:

\section{$H_{10}$ : Long-established firm may disclose more information than newly-established firms.}

\section{Research Methodology}

\subsection{Sample Selection}

The study has been conducted on a sample of 60 arbitrarily selected firms listed on the BSE / NSE during the study period from 2000-01 to 2009-10. The research data have been collected from the 
published annual reports which are available in the websites of the respective firms under study. In this study, six industrial sectors have been considered viz. Automobile, Fertilizers, FMCG, Information Technology, Pharmaceutical and Steel.

\subsection{Preparation of a list of disclosure information}

On the issue of measuring the level of corporate disclosure, the Standard \& Poor (2008) model has been used. Following suggestion of Standard \& Poor, 106 disclosure items have been considered for this study. As per the said suggestion, these 106 items have been segregated into three broad categories, (i) Ownership Structure and Investor Relations (32 items), (ii) Financial Transparency \& Information Disclosure (37 items) and (iii) Board and Management Structure \& Process (37 items).

\subsection{Scoring of the disclosure index}

For assignment of weights to corporate disclosure items two popular approaches have been used in the previous studies. The first approach is the 'weighted disclosure index' and the other approach is 'un-weighted disclosure index'. Weighted disclosure index gives emphasis on the relative importance of disclosure items to the users of the financial reports. Un-weighted disclosure index assumes that each item to be equally important.

Researchers such as Courtis (1978), Marston (1986) have used weighted disclosure index. On the other hand, Un-weighted disclosure index has been used in few studies (Cooke, 1989, 1991; Hossain et al., 1994; Raffournier, 1995; Narasimhan \& Vijayalakshmi, 2006; Aljifri, 2008; Akhtartuddin et al., 2009). Both weighted disclosure index as well as Un-weighted disclosure index have been used in some research studies (Singhvi \& Desai, 1971; Choi, 1973; Mangena \& Pike, 2005). In this present study, however, an un-weighted disclosure index has been used.

The percentage of actual disclosure with respect to the suggested disclosures by Standard \& Poor, has been used here to assess the extent of corporate disclosure. For developing firm-specific disclosure score the methodology that has been used is: if a firm discloses an item of information included in the disclosure list of Standard \& Poor, it has been assigned a score of 1, and 0 if it fails to disclose the same. Following the guideline of Standard \& Poor (2008) maximum corporate disclosure score of a firm can be 106. Percentage of actual corporate disclosure has been computed year-wise for every company over the 10 year study period. The method used for computing the corporate disclosure index for each company can be expressed as follows:

$C D I=\frac{\text { Total un-weighted score obtained by the company }}{\text { Total score applicable to the company (as per Standard \& Poor) }} \times 100$

\subsection{Dependent and independent variable of the study}

The Corporate disclosure index (CDI) has been used as the dependent variable and the independent variables are: board size, board composition, ratio of audit committee members to total board members, family control, CEO duality, firm size, profitability, leverage, liquidity and age of the firm.

\subsection{Descriptive statistics}

The descriptive statistics are used to provide summarize views of the dependent and independent variables. For this purpose, mean, minimum value, maximum value and standard deviation have been computed for the entire study period. The observed values are then discussed in the following subsection 5.1. 


\subsection{Model development}

The multiple regression model used to test the association between firm characteristics, corporate governance attributes and the level of corporate disclosure is presented below:

$$
\begin{gathered}
C D I_{i t}=\alpha+\beta_{1} B D S Z_{i t}+\beta_{2} B C_{i t}+\beta_{3} R A C_{i t}+\beta_{4} F C_{i t}+\beta_{5} C E O D_{i t}+\beta_{6} L T A_{i t} \\
+\beta_{7} P R F T_{i t}+\beta_{8} L V_{i t}+\beta_{9} L Q_{i t}+\beta_{10} A G E_{i t}+\varepsilon_{i t}
\end{gathered}
$$

where:

$C D I_{i t}=$ Corporate disclosure index of the $i^{\text {th }}$ company in the $t^{\text {th }}$ year,

$B D S Z_{i t}=$ Board size of the $\mathrm{i}^{\text {th }}$ company in the year $\mathrm{t}$,

$B C_{i t} \quad=$ Ratio of non-executive directors to total members in the board of the ith firm during year $\mathrm{t}$,

$R A C_{i t} \quad=$ Proportion of audit committee members to total members in the board of the ith firm during the year $\mathrm{t}$,

$F C_{i t} \quad=$ Presence of family control in the board of the $\mathrm{i}^{\text {th }}$ company in the year $\mathrm{t}$,

$C E O D_{i t}=$ Role of chairman and CEO by the same person of the $\mathrm{i}^{\text {th }}$ firm in period $\mathrm{t}$,

$L T A_{i t} \quad=$ Log value of total asset of $i^{\text {th }}$ company in the $t^{\text {th }}$ year,

$\operatorname{PRFT}_{i t} \quad=$ Profitability of the $\mathrm{i}^{\text {th }}$ company in the year $\mathrm{t}$,

$L V{ }_{i t} \quad=$ Leverage of the $i^{\text {th }}$ company in the period $\mathrm{t}$,

$L Q_{i t} \quad=$ Liquidity of the $i^{\text {th }}$ company in the year,

$A G E_{i t} \quad=$ Age of the $\mathrm{i}^{\text {th }}$ company in the period $\mathrm{t}$,

$\alpha \quad=$ the constant,

$\beta \quad=$ the slope of the regression equation, and

$\varepsilon_{i t} \quad=$ the error term.

\subsection{Multicollinearity Test}

The study is concerned with the individual effect of the explanatory variables on the level of corporate disclosure. As these values, in a large part, represent the accounting numbers generated by firm, interrelationships among them are expected. Hence, the presence of multicollinearity is required to be tested and, if necessary, should be converted in order to specify an appropriate model that can be efficiently used for the present purpose. Earlier research studies have used the techniques like simple correlation and VIF for examining the presence of multicollinearity (Akhtaruddin et al., 2009 and Hossain \& Hammami, 2009). In the present study, in addition to simple correlation and VIF, the presence of multicollinearity has tested by using the tolerance value following the suggestion of Gujrati (2004). The results of the multicollinearity are discussed in the sub-section 5.2.

\subsection{Multiple regression analysis}

As mentioned earlier in sub-section 4.6, the regression analysis has been used to assess the association between corporate disclosure level (dependent variable) and several independent variables (board size, board composition, ratio of audit committee members to total board members, family control, CEO duality, firm size, profitability, leverage, liquidity and age of the firm). In sub-section 5.3 the results of the multiple regression analysis have been discussed. 


\section{Results}

\subsection{Descriptive Statistics}

As mentioned in earlier, descriptive statistics for the dependent variable and independent variables are reported in Table 1.

\section{Table 1}

Descriptive Statistics for All Variables

\begin{tabular}{|c|c|c|c|c|}
\hline Variables & Minimum & Maximum & Mean & Std. Deviation \\
\hline Corporate Disclosure Index (CDI) & 35.85 & 75.47 & 62.4205 & 4.79377 \\
\hline Board Size (BDSZ) & 4.00 & 27.00 & 10.3400 & 3.73528 \\
\hline Board Composition (BC) & 0.32 & 0.89 & 0.6803 & 0.26869 \\
\hline Ratio of Aud. Comm. Members (RAC) & 0.00 & 0.78 & 0.4242 & 0.13526 \\
\hline Family Control (FC) & 0.00 & 1.00 & 0.4520 & 0.49819 \\
\hline CEO Duality (CEOD) & 0.00 & 1.00 & 0.6200 & 0.48587 \\
\hline Log Value of Total Assets (LTA) & 0.24 & 4.56 & 2.8567 & 0.79681 \\
\hline Profitability (PRFT) & -15.38 & 124.97 & 11.8485 & 10.98509 \\
\hline Leverage (LV) & 0.00 & 6.50 & 0.3494 & 0.66706 \\
\hline Liquidity (LQ) & 0.35 & 5.40 & 2.9632 & 3.64522 \\
\hline Age of the firm (AGE) & 3.00 & 164.00 & 33.6500 & 32.62754 \\
\hline
\end{tabular}

The results from the corporate disclosure index (CDI) indicate that the minimum score achieved by a firm is 35.85 and the maximum score is 75.47 with a standard deviation of 4.794 percent. It is also found that the selected Indian firms, on average, disclose 62.42 percent of the items of information to be disclosed as per Standard \& Poor (2008) specification. Compared to the levels of disclosures as observed by Patel et al., (2002) at 39\% the present study evidences that considerable improvement has been taken place during the study period.

The mean value of the board (BDSZ) size is 10.34 with minimum and maximum sizes are 4 and 27 respectively. The mean of the proportion of the non-executive directors $(\mathrm{BC})$ to the total board members on the board is 68.03 percent, which shows that a large number of directors are nonexecutive directors. The mean value of ratio of audit committee members (RAC) show that on an average the substantial portion of the total board members has been chosen from the audit committee members $(42.42 \%)$ by the firms in India. The mean value of family (FC) control is 45.20 percent which denotes that in India, a significant portion of firms are controlled by the family. The average value of CEO duality (CEOD) is 0.62 . This indicates that on an average $62 \%$ of the Indian firms have engaged two different persons as chairman and CEO (i.e. CEO duality) in order to manage the affairs of the business.

The minimum value of firm size (LTA) is 0.24 and the maximum value is 4.56 . This firm size value denotes that the firms are expansively dispersed. The statistics on the profitability (PRFT) reveal that profitability varies between $-15.38 \%$ (negative profit) and $124.97 \%$ (maximum profit) which, in turn, focuses on the wide variability $(\mathrm{SD}=10.985)$ in the profit generating ability of the selected firms. However, the average profitability value is found to be moderate (mean $=11.849$ ) which speaks for the moderate efficiency level of selected Indian firms. The mean value of leverage (LV) ratio is 34.94 percent which indicates that long-term debt occupies a significant portion in the capital structure. In this study, the selected firms have followed a conservative approach. The mean value of liquidity (LQ) ratio is 2.96, indicates that the short-term loan payment capacity of the selected firms are very high. Firm age (AGE) ranges from 3 to 164 with a mean of 33.65 for the full sample.

\subsection{Multicollinearity Analysis}


As mentioned in the previous sub-section 4.7, the multicollinearity in the explanatory variables have been diagnosed through the analysis of correlation factors and Variable Inflation Factors (VIF).

Table 2

Pearson Correlation Analysis Results

\begin{tabular}{|c|c|c|c|c|c|c|c|c|c|c|c|}
\hline Variable & CDI & BDSZ & $\mathrm{BC}$ & RAC & $\mathrm{FC}$ & CEOD & LTA & PRFT & LV & LQ & AGE \\
\hline CDI & 1.000 & & & & & & & & & & \\
\hline BDSZ & $0.242 * *$ & 1.000 & & & & & & & & & \\
\hline $\mathrm{BC}$ & 0.068 & $-0.123 * *$ & 1.000 & & & & & & & & \\
\hline RAC & $0.146 * *$ & $0.659 * *$ & $0.179 * *$ & 1.000 & & & & & & & \\
\hline $\mathrm{FC}$ & 0.080 & $-0.259 * *$ & 0.019 & 0.082 & 1.000 & & & & & & \\
\hline CEOD & 0.063 & $0.146^{* *}$ & 0.033 & -0.045 & 0.001 & 1.000 & & & & & \\
\hline LTA & $0.550 * *$ & $0.646^{* *}$ & 0.042 & $0.499 * *$ & $-0.222 * *$ & $0.215^{* *}$ & 1.000 & & & & \\
\hline PRFT & $0.102 *$ & 0.024 & -0.001 & -0.078 & $-0.134 * *$ & -0.049 & 0.053 & 1.000 & & & \\
\hline LV & -0.009 & $0.141^{* *}$ & -0.052 & -0.033 & $0.163 * *$ & 0.064 & $0.089 *$ & $-0.141 * *$ & 1.000 & & \\
\hline LQ & $0.116 * *$ & $-0.205 * *$ & -0.079 & $0.141 * *$ & -0.057 & $-0.217 * *$ & $0.296 * *$ & $0.163 * *$ & -0.072 & 1.000 & \\
\hline AGE & $0.140 * *$ & $0.201 * *$ & -0.025 & $-0.148 * *$ & -0.059 & $0.268 * *$ & $0.404 * *$ & -0.062 & -0.033 & $-0.181 * *$ & 1.000 \\
\hline
\end{tabular}

** Correlation is significant at the 0.01 level (2-tailed).

* Correlation is significant at the 0.05 level (2-tailed).

The Pearson correlation analysis reported in Table 2, reveals that the highest simple correlation between independent variables is 0.659 between board size and ratio of audit committee members to total board members. According to Gujrati (2004) and Hair et al. (2011) the simple correlation not exceeding 0.90 between the independent variables should not be considered harmful. The VIF values higher than 10 are likely to cause a multicollinearity problem (Gaur \& Gaur, 2009). As the VIF values range between 2.621 and 1.116 (i.e., for less than 10), it may be argued that collinearity is not a problem for this regression model. The tolerance is another measure of multicollinearity. As suggested by Hair et al. (2011), the tolerance value more than 0.20 may be used as a criterion for considering the data being free from the problem of multicollinearity. The calculated tolerance values vary between 0.381 and 0.896 , and hence, indicate that there is no collinearity between the independent variables.

\subsection{Discussion of regression result}

As mentioned in proceeding section 4.8, the study has used a multiple regression model to study the influence of firm-specific factors on the levels of corporate disclosure variables. The results of pertaining to the regression model are presented in Table 3 . The R-square values vary between 0.446 and 0.526 . The observed R-square values indicate that the explanatory power of the selected independent variables together varies between $44.6 \%$ and $52.6 \%$ (minimum of $44.6 \%$ and maximum of $52.6 \%)$.

Table 3

Regression Result of Corporate Disclosure Index, Firm Characteristics and Corporate Governance Attributes (Year-wise)

\begin{tabular}{|c|c|c|c|c|c|c|c|c|c|c|c|c|c|}
\hline Year & Constant & BDSZ & $\mathrm{BC}$ & RAC & $\mathrm{FC}$ & CEOD & LTA & PRFT & $\mathrm{LV}$ & LQ & AGE & $\mathrm{R}^{2}$ & F-Stat \\
\hline $2000-01$ & $\begin{array}{r}48.201^{* *} \\
(6.169)\end{array}$ & $\begin{array}{r}0.134 \\
(0.335)\end{array}$ & $\begin{array}{r}-1.559 \\
(-0.303)\end{array}$ & $\begin{array}{r}4.571 \\
(0.516)\end{array}$ & $\begin{array}{l}3.414^{*} \\
(2.323)\end{array}$ & $\begin{array}{r}-0.021 \\
(-0.014)\end{array}$ & $\begin{array}{r}3.611^{* *} \\
(3.176)\end{array}$ & $\begin{array}{l}0.100^{*} \\
(2.520)\end{array}$ & $\begin{array}{r}-0.405 \\
(-0.316)\end{array}$ & $\begin{array}{r}0.044 \\
(0.464)\end{array}$ & $\begin{array}{r}-0.031 \\
(-1.279)\end{array}$ & 0.451 & $2.839 * *$ \\
\hline 2001-02 & $\begin{array}{r}39.719 * * \\
(5.778)\end{array}$ & $\begin{array}{r}0.388 \\
(1.184)\end{array}$ & $\begin{array}{r}-3.835 \\
(-0.763)\end{array}$ & $\begin{array}{r}16.513^{*} \\
(2.028)\end{array}$ & $\begin{array}{l}4.567^{*} \\
(3.430)\end{array}$ & $\begin{array}{r}0.595 \\
(0.435)\end{array}$ & $\begin{array}{r}3.896^{* *} \\
(3.106)\end{array}$ & $\begin{array}{l}0.163^{*} \\
(2.474)\end{array}$ & $\begin{array}{r}-0.813 \\
(-1.042)\end{array}$ & $\begin{array}{r}0.114 \\
(0.637)\end{array}$ & $\begin{array}{r}-0.016 \\
(-0.702)\end{array}$ & 0.526 & $3.830 * *$ \\
\hline $2002-03$ & $\begin{array}{r}45.272 * * \\
(7.796)\end{array}$ & $\begin{array}{r}0.186 \\
(0.601)\end{array}$ & $\begin{array}{r}0.316 \\
(0.064)\end{array}$ & $\begin{array}{r}7.518 \\
(1.333)\end{array}$ & $\begin{array}{l}3.242 * \\
(2.802)\end{array}$ & $\begin{array}{r}0.457 \\
(0.362)\end{array}$ & $\begin{array}{r}4.033 * * \\
(3.734)\end{array}$ & $\begin{array}{r}0.014 \\
(0.309)\end{array}$ & $\begin{array}{r}-0.870 \\
(-1.232)\end{array}$ & $\begin{array}{r}0.138 \\
(0.809)\end{array}$ & $\begin{array}{r}-0.023 \\
(1.169)\end{array}$ & 0.470 & $3.068 * *$ \\
\hline 2003-04 & $\begin{array}{r}46.775 * * \\
(7.364)\end{array}$ & $\begin{array}{l}-0.016 \\
(-0.052)\end{array}$ & $\begin{array}{r}-2.457 \\
(-0.466)\end{array}$ & $\begin{array}{r}9.470 \\
(1.628)\end{array}$ & $\begin{array}{l}3.719^{*} \\
(3.070)\end{array}$ & $\begin{array}{r}0.304 \\
(0.239)\end{array}$ & $\begin{array}{r}4.407 * * \\
(3.970)\end{array}$ & $\begin{array}{r}0.063 \\
(1.011)\end{array}$ & $\begin{array}{r}-0.568 \\
(-0.674)\end{array}$ & $\begin{array}{r}0.061 \\
(0.356)\end{array}$ & $\begin{array}{r}-0.030 \\
(-1.544)\end{array}$ & 0.499 & $3.439 * *$ \\
\hline 2004-05 & $\begin{array}{r}50.707 * * \\
(9.556)\end{array}$ & $\begin{array}{r}0.212 \\
(0.840)\end{array}$ & $\begin{array}{r}-2.918 \\
(-0.621)\end{array}$ & $\begin{array}{r}4.984 \\
(1.020)\end{array}$ & $\begin{array}{l}2.667^{*} \\
(2.262)\end{array}$ & $\begin{array}{r}0.233 \\
(0.219)\end{array}$ & $\begin{array}{r}4.675^{* *} \\
(4.985)\end{array}$ & $\begin{array}{r}0.079 \\
(1.326)\end{array}$ & $\begin{array}{r}-0.279 \\
(-0.215)\end{array}$ & $\begin{array}{r}0.135 \\
(0.624)\end{array}$ & $\begin{array}{r}-0.024 \\
(-1.379)\end{array}$ & 0.524 & $3.799 * *$ \\
\hline 2005-06 & $\begin{array}{r}49.607 * * \\
(9.173)\end{array}$ & $\begin{array}{r}0.076 \\
(0.324)\end{array}$ & $\begin{array}{r}-3.563 \\
(-0.748)\end{array}$ & $\begin{array}{r}5.977 \\
(1.123)\end{array}$ & $\begin{array}{l}2.559^{*} \\
(2.296)\end{array}$ & $\begin{array}{r}-0.052 \\
(-0.047)\end{array}$ & $\begin{array}{r}4.653^{* *} \\
(4.794)\end{array}$ & $\begin{array}{r}0.055 \\
(0.682)\end{array}$ & $\begin{array}{r}-0.126 \\
(-0.116)\end{array}$ & $\begin{array}{r}0.139 \\
(0.507)\end{array}$ & $\begin{array}{r}-0.026 \\
(-1.436)\end{array}$ & 0.513 & $3.636^{* *}$ \\
\hline 2006-07 & $\begin{array}{r}50.588^{* * *} \\
(8.846)\end{array}$ & $\begin{array}{r}0.109 \\
(0.605)\end{array}$ & $\begin{array}{r}-3.188 \\
(-0.600)\end{array}$ & $\begin{array}{r}5.340 \\
(0.965)\end{array}$ & $\begin{array}{r}1.823 \\
(1.674)\end{array}$ & $\begin{array}{r}0.142 \\
(0.130)\end{array}$ & $\begin{array}{r}4.615^{* *} \\
(4.613)\end{array}$ & $\begin{array}{r}0.119 \\
(1.454)\end{array}$ & $\begin{array}{r}-0.031 \\
(-0.031)\end{array}$ & $\begin{array}{r}0.089 \\
(0.361)\end{array}$ & $\begin{array}{r}-0.020 \\
(-1.171)\end{array}$ & 0.516 & $3.677 * *$ \\
\hline $2007-08$ & $\begin{array}{r}50.344 * * \\
(7.523)\end{array}$ & $\begin{array}{r}0.019 \\
(0.102)\end{array}$ & $\begin{array}{r}0.196 \\
(0.038)\end{array}$ & $\begin{array}{r}2.943 \\
(0.516)\end{array}$ & $\begin{array}{r}0.919 \\
(0.815)\end{array}$ & $\begin{array}{r}0.541 \\
(0.461)\end{array}$ & $\begin{array}{r}4.312 * * \\
(3.774)\end{array}$ & $\begin{array}{r}-0.007 \\
(-0.113)\end{array}$ & $\begin{array}{r}0.222 \\
(0.236)\end{array}$ & $\begin{array}{r}-0.007 \\
(-0.021)\end{array}$ & $\begin{array}{r}-0.020 \\
(-1.152)\end{array}$ & 0.446 & $2.776^{* *}$ \\
\hline 2008-09 & $\begin{array}{r}52.986^{* *} \\
(6.339)\end{array}$ & $\begin{array}{r}0.071 \\
(0.395)\end{array}$ & $\begin{array}{r}-2.670 \\
(-0.562)\end{array}$ & $\begin{array}{r}3.317 \\
(0.584)\end{array}$ & $\begin{array}{r}0.708 \\
(0.640)\end{array}$ & $\begin{array}{r}0.560 \\
(0.516)\end{array}$ & $\begin{array}{r}4.431^{* *} \\
(4.450)\end{array}$ & $\begin{array}{r}0.026 \\
(0.465)\end{array}$ & $\begin{array}{r}-0.064 \\
(-0.073)\end{array}$ & $\begin{array}{r}0.107 \\
(0.342)\end{array}$ & $\begin{array}{r}-0.023 \\
(-1.371)\end{array}$ & 0.468 & $3.039 * *$ \\
\hline $2009-10$ & $\begin{array}{r}48.483 * * \\
(5.520)\end{array}$ & $\begin{array}{r}0.046 \\
(0.264)\end{array}$ & $\begin{array}{r}0.982 \\
(1.492)\end{array}$ & $\begin{array}{r}3.206 \\
(0.571)\end{array}$ & $\begin{array}{r}0.780 \\
(0.744)\end{array}$ & $\begin{array}{r}0.564 \\
(0.526)\end{array}$ & $\begin{array}{r}4.822 * * \\
(4.940)\end{array}$ & $\begin{array}{r}0.017 \\
(0.275)\end{array}$ & $\begin{array}{r}0.143 \\
(0.166)\end{array}$ & $\begin{array}{r}0.266 \\
(0.871)\end{array}$ & $\begin{array}{r}-0.016 \\
(-1.032)\end{array}$ & 0.526 & $3.827 * *$ \\
\hline
\end{tabular}

**Regression is significant at $1 \%$ leve

$*$ Regression is significant at $10 \%$ level 
This means that the selected independent variables together moderately explain the variances of corporate disclosure level. Some of the earlier research studies, however, have reported better explanatory power using different sets of independent variables [Hossain (2008) at 53.80 percent, Akhtaruddin (2005) at 57.70 percent and Haniffa \& Cooke (2002) at 58.30 percent]. Conventionally, $\mathrm{F}$ statistic with a $\mathrm{p}$ value less than 0.01 is used as a measure of goodness of fit the model used to examine the impact of a set of independent variable. The observed $\mathrm{F}$ values are higher than the table value at $p=0.10$ level which speak in favour of the appropriation of the regression model employed in the present study. Hence, based on the values of R-square and F-statistic it may be argued that the multiple regression model used in this study has a good explanatory power.

Corporate disclosure score and board size (BDSZ) is found to be positively related in all the years except in the year 2003-04. These multiple regression results support the argument that the larger boards provide more corporate information than the smaller firms. The positive effect of board size on the level of corporate disclosure is consistent with Akhtaruddin et al., (2009) and Allegrini \& Greco (2011). A negative relationship is observed between the board composition (BC) and the corporate disclosure level in all the years except in the years 2002-03, 2007-08 and 2009-10. The results suggest that firms with a higher proportion of non-executive directors disclose less corporate information. Empirical evidences (excluding of the three years mentioned earlier) of the study are consistent with those reported by Ho \& Wong (2001) and Barako et al. (2006) in respect of the association between the board composition and the extent of corporate disclosure.

Corporate disclosure level and audit committee size (RAC) is found to be positively associated in all the years though not statistically significant excepting in the year 2001-02. This indicates that the higher proportion of audit committee members on the board may have positive impact on the level of corporate disclosure. Relating to family control (FC), the result of the study indicates that family control is positively related with the degree of corporate disclosure. Thus, the hypothesis 4 is not found to be supported by the empirical evidences of the present study. However, in respect of the association between the level of corporate disclosure and the CEO duality (CEOD), the observed empirical findings support the a-priori relationship in all the years except in the years 2000-01 and 2005-06.

The present study identifies the firm size (LTA) as the most significant firm characteristic variable influencing the corporate disclosure practices in India. The hypothesis that 'the big firms disclose more information than the small firms' is supported $(p<.01)$. The finding is consistent with those of the prior studies (Chow \& Wong-Boren, 1987; Cooke, 1989; Hossain et al., 1994; Wallace \& Naser, 1995; Owusu-Ansah, 1998; Haniffa \& Cooke, 2002). In case of profitability (PRFT), however, a mixed result is found. This independent variable is such to be positively associated with the level of corporate disclosure in all the years except in the year 2007-08. This observed positive effect of profitability on the degree of corporate disclosure is consistent with Wallace et al. (1994), Karim (1996), Owusu-Ansah (1998), and Hossain (2000). These results suggest that managers of profitable firms will disclose more accounting information in the annual reports to justify their salaries (Singhvi \& Desai, 1971). Lang and Lundholm (1993) suggest that profitable firms provide more information in the financial reports than do the less or negative profitable firms. In contrast with the hypothesized relationship, leverage (LV) and the level of corporate disclosure is found to be negatively associated in all the years except in the years 2007-08 and 2009-10. The negative effect of the leverage on the extent of corporate disclosure is consistent with the empirical findings of the study conducted by Allegrini \& Greco (2011). As regards the relationship between corporate disclosure level and liquidity (LQ), a positive association is observed in all the years except in the year 2007-08. Thus, the hypothesized association is found to be supported by and large by the empirical evidences of the present research study. Relating to the age of the firm (AGE), the result of the study does not advocate the hypothesized relationship. This empirical evidence is consistent with that reported by 
Akhtaruddin, (2005). However, Owusu-Ansah (1998) and Hossain (2008) have found a positive association between the said variables.

\section{Conclusion}

This study investigates the association between firm characteristics, corporate governance attributes and the level of corporate disclosure of 60 listed firms in India during the study period ranging between 2000-01 and 2009-10. The study indicates that the corporate disclosure level of the selected listed firms in India depends on some corporate governance attributes and firm characteristics. Regarding the association between corporate governance attributes and the extent of corporate disclosure, a positive association is found between board size, ratio of audit committee members to total board members, family control, CEO duality and the degree of corporate disclosure. However, board composition is negatively related to the level of corporate disclosure. While in case of most of the selected variables the hypothesized associations are found to have been supported by the empirical findings, in case of family control and board composition contrary observations have been obtained. Hence, reasons for such inconsistencies are required to be further investigated.

About the relationship between firm characteristics and corporate disclosure score, a negative association is observed between leverage, age of the firm and the extent of corporate disclosure. However, the firm size, profitability and liquidity are seen to have positively influenced the degree of corporate disclosure. In so far as the hypothesized associations of the level of corporate disclosure and firm-specific variables are concerned, the empirical findings appear to be different in case of leverage and age of the firm. Positive influence in both the cases is normally expected. Hence, the reasons behind these contrary findings need to be further investigated. A plausible explanation of the reported unusual association in case of leverage may be that for closely held firms (whose free-float shares are comparatively less) it is possible to keep the disclosure level low. Particularly in the context of a less vibrant debt market, firms generally try to tap the institutional investors segment (in many cases banks and non-banking financial institutions) for the purpose of raising debt funds. Under such a situation, provides of debt funds may not urge upon the firms for a higher level of public disclosure; rather they may put emphasis on the submission of the required information by the firms which are necessary for assessing the privately placed debt instruments. Hence, for a closely held levered firm, a negative association between level of corporate disclosure and leverage is possible. Similarly, for a closely held age old firm, a positive association between degree of corporate disclosure and age of the firm may not observed.

\section{Limitations and future research direction}

In spite of a sincere effort to accomplish the stated objective, the present research study is not free from limitations. The first and foremost concern in this respect in the sample size which act as the constraint for generalizing the observed findings in the Indian context. For ensuring generalization, one needs to reinvestigate the identified issue using a fairly large data set for a sufficiently long period of time. The data set should also cover all the sectors of Indian industries. Measurement of variables also needs to be reviewed and alternative appropriate techniques may also be used. Also, attention should be paid to use some improved methodology which may be helpful in specifying an appropriate model for the stated purpose. Some other important variables namely audit firm size, asset-in-place and firm value which have used by a few earlier studies may also be included in the model to find out the degree of various determinants of corporate disclosures.

\section{References}

Ahmed, K. \& Courtis, J. K. (1999). Association between Corporate Characteristics and Disclosure Levels in Annual Reports: A Meta Analysis. British Accounting Review, 31, 35-61. 
Aksu, M., \& Kosedag, A. (2005). The Relationship between Transparency \& Disclosure and Firm Performance: Evidence from the Istanbul Stock Exchange. Working Paper, Sabanchi University.

Akhtaruddin, M. (2005). Corporate mandatory disclosure practices in Bangladesh. International Journal of Accounting, 40 (4), 399-422.

Akhtartuddin, M., Hossain, M. A., Hossain, M., \& Yao, L. (2009). Corporate governance and voluntary disclosure in corporate annual reports of Malaysian listed firms. JAMAR, 7 (1), 1-20.

Aljifri, K. (2008). Annual report disclosure in a developing country: The case of the UAE. Advances in Accounting, 24, 93-100.

Allergrini, M. \& Greco, G. (2011). Corporate boards, audit committees and voluntary disclosure: evidence from Italian listed Companies. Journal of Management \& Governance

Barako, D.G., Hancock, P. \& Izan, H. Y. (2006). Factors influencing voluntary corporate disclosure by Kenyan companies. Corporate Governance: An International Review, 14 (2), 107-125.

Chau, G. K. \& Gray, S. J. (2002). Ownership structure and corporate voluntary disclosure in Hong Kong and Singapore. The International Journal of Accounting, 37 (2), 247-265.

Chen, C. J. P. \& Jaggi, B. (2000). Association between Independent Non-Executive Directors, Family Control and Financial Disclosure in Hong Kong. Journal of Accounting and Public Policy, 19, 285-310.

Choi, F. D. S. (1973). Financial disclosure and Entry to European Markets. Journal of Accounting Research, 2, $155-179$.

Chow, C. W., \& Wong-Boren, A. (1987). Voluntary Financial Disclosure by Mexican corporations. The Accounting Review, 62 (3), 533-541.

Cooke, T. E. (1989). Disclosure in the Corporate Annual Report of Swedish Companies. Accounting and Business Research, 19 (74), 113-124.

Cooke, T. E. (1991). An assessment of voluntary disclosure in the annual reports of Japanese Corporations. The International Journal of Accounting, 26, 174-189.

Das, D., Dhar, S. and Gandhi, S. K. (2008). Mandatory Disclosure in Annual Reports of Companies Listed in Indian Stock Exchanges: Extent and Determinants. Indian Accounting Review, 12 (1), 18-37.

Eng, L. L. \& Mak, Y. T. (2003). Corporate governance and voluntary disclosure. Journal of Accounting and Public Policy, 22, 325-345.

Fama E.F. \& Jensen M.C. (1983). Separation of Ownership and Control. Journal of Law and Economics, 26, 301-325.

Firth, M. (1979). The Effect of Size, Stock Market Listings and Auditors on Voluntary Disclosure in Corporate Annual Reports. Accounting and Business Research, 9 (36), 273-280.

Ghosh, S. K. \& Nandi, S. (2009). Impact of Corporate Governance and other Firm Characteristics on Transparency \& Disclosure (T \& D): An Empirical Study. Annamalai Journal of Management, July 2009, 94-101.

Gour, A. S. \& Gour, S. S. (2009). Statistical Methods for Practice and Research. Second Edition. Response Books.

Gujarati, D. N. (2004). Basic Econometrics. Forth Edition, New Delhi, Tata McGraw-Hill Publishing Company Limited.

Hair, J. F., Black, W. C., Babin, B. J., Anderson, R. E., \& Tatham R. L. (2011). Multivariate Data Analysis. Sixth Edition, Pearson.

Haniffa, R. M., \& Cooke, T.E. (2002). Culture, Corporate Governance and Disclosure in Malaysian Corporations. Abacus, 38 (3), $317-349$.

Healy, P. M., \& Palepu, K. G. (2001). Information Asymmetry, Corporate Disclosure and the Capital Markets: A Review of the Empirical Disclosure Literature. Journal of Accounting and Economics, 31, 405-440.

Ho, S.S.M. \& Wong, K.S. (2001). A study of the relationship between corporate governance structure and the extent of voluntary disclosure. Journal of International Accounting, Auditing and Taxation, 10 (2), 139-156. 
Hossain, M (2008). The extent of disclosure in annual reports of banking companies: The Case of India. European Journal of Scientific Research, 23 (4), 659-680.

Hossain, M., Tan, L. M., \& Adams, M. (1994). Voluntary disclosure in an emerging capital market: Some empirical evidence from companies listed on the Kuala Lumpur Stock Exchange. The International Journal of Accounting, Urbana, 29 (4), 334-351.

Hossain, M., \& Hammami, H. (2009). Voluntary disclosure in the annual reports of an emerging country: The case of Qatar. Advances in Accounting, incorporating Advances in International Accounting, 25, 255-265.

Jensen, M. C., \& Meckling, W. H. (1976). Theory of the firm: Managerial behavior, agency costs and ownership structure. Journal of Financial Economics, 3, 305-360.

Karim, A.K.M.W. (1996). The association between corporate attributes and the extent of corporate disclosure. Journal of Business Studies, University of Dhaka, 17 (2), 89- 124.

Lang, M. H. \& Lundholm, R. J. (1993). Cross-sectional Determinants of Analysts Ratings of Corporate Disclosures. Journal of Accounting Research, 31 (2), 246-271.

Leftwich, R., Watts, R. L., \& Zimmerman, J. L. (1981). Voluntary corporate disclosure: the case of interim reporting. Journal of Accounting Research, 19, 50-77.

Mangena, M. \& Pike, R. (2005). The effect of audit committee shareholding, financial expertise and size on interim financial disclosures. Accounting and Business Research, 35 (4), 327-349.

Marston, C. L. (1986). Financial reporting practices in India. London: Croom Helm.

Moody's-ICRA Corporate Finance (2007). Corporate Governance and Related Credit Issues for Indian Family-Controlled Companies. October, Special Comment.

Nagina, R. S. (2005). Disclosure Practices of Corporate Sector. New Century Publications, New Delhi, India.

Narasimhan, M. S., \& Vijayalakshmi, S. (2006). Corporate Disclosure and Firm Characteristics in India. The Icfai Journal of Accounting Research, 5 (4), 38-53.

Owusu-Ansah (1998). The Impacts of Corporate Attributes on the Extent of Mandatory Disclosure and Reporting by Listed Companies in Zimbabwe. The International Journal of Accounting, 33 (5), 605-631.

Piesse, J., Filatotchev, I. \& Lien Y. (2007). Corporate Governance in Family- controlled Firms in Taiwan. RISEC, 54 (1), 176-193.

Raffournier, B. (1995). The determinants of voluntary financial disclosure by Swiss listed companies, European Accounting Review, 42, 261-280.

Rouf, M. A., (2010). Corporate Characteristics, Governance attributes and the extent of Voluntary disclosure in Bangladesh. Asian Journal of Management Research, 166-183.

Singhvi, S., \& Desai, H. B. (1971). An Empirical Analysis of the Quality of Corporate Financial Disclosure. Accounting Review, 46 (1), 621-632.

Standard \& Poor's (2008). Corporate Governance: Turkish Transparency And Disclosure Survey 2008: A Year Of Little Or No Progress. Ratings Direct on the Global Credit Portal (September 18, 2008). Retrieved from the website: www.standardandpoors.com/ratingsdirect )

Wallace, R.S.O. \& Naser, K. (1995). Firm-Specific Determinants of Comprehensiveness of Mandatory Disclosure in the Corporate Annual Reports of Firms on the Stock Exchange of Hong Kong. Journal of Accounting and Public Policy, 14, 311-368.

Wallace, R. S. O., Naser, K. \& Mora, A. (1994). The Relationship between the Comprehensiveness of Corporate Annual Reports and Firm Characteristics in Spain. Accounting and Business Research, 25 (97), 41-53.

Watts, R., \& Zimmerman, J. (1986). Positive Accounting Theory. Englewood Cliffs, N. j.: PrenticeHall, Inc.

Zahra, S.A. Neubaum, D.O. \& Huse, M. (2000). Entrepreneurship in medium-size companies: exploring the effects of ownership and governance systems. Journal of Management, 26 (5), 947976. 